\title{
A missing hand at the dinner table: The response to the plight of farmers in South Africa
}

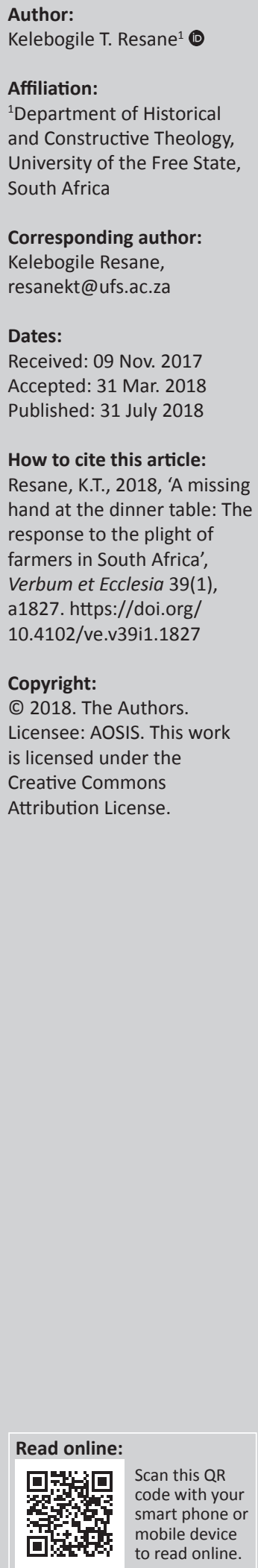

This article investigated the plight of farmers in South Africa. The intention is to enlighten South Africans of the importance of farming and the respect of farmers' life and dignity. It starts by giving the picture of how the farmers are marginalised even in thanksgiving for food. Acknowledgement is always given to the provider (God) and the preparer (cook), while the producer (farmer) is unmentioned in appreciation for food. There is a demonstration that Godhuman dealings from the beginning were around the garden. Communication of God with a human being was in the garden; and humanity expressed wisdom, sexual intimacy, and livelihood in and around the farm. A historical survey of farming from the hunter-gatherers up to the commercial farmers of today is pointed out. The current farm attacks in South Africa are explored through press releases, political statements, and periodicals. Suggestions to address these attacks through political initiatives, land restitution, decolonised agricultural sciences, and the role the church should play are suggested. The farmer as the food provider is to be respected as a human being that carries the image of God.

Intradisciplinary and/or Interdisciplinary implications: The article addresses the importance of farmers, the history of farming in Southern Africa and the biblical basis for agriculture. The burning issue of farm attacks is a main concern and needs to be addressed through political dialogue, decolonisation of agricultural sciences and church's participation in teaching the nation the value of farmers as human beings regardless of the colour of their skins.

\section{Introduction}

Many South Africans grow up religious. Prayers offered before meals are part of tradition. These prayers come in different names such as blessing the food, saying grace over the food or even sanctifying the food. Our nation from childhood is initiated and indoctrinated in praying over food. Some of these prayers are said at rote level. The prayers by adults go like this:

- Bless, O Lord, this food to our use and us to thy service, and keep us ever mindful of the needs of others. In Jesus' name, Amen.

- For this and all we are about to receive, make us truly grateful, Lord. Through Christ we pray. Amen.

- For good food and those who prepare it, for good friends with whom to share it, we thank you Lord.

- For food in a world where many walk in hunger; For faith in a world where many walk in fear; For friends in a world where many walk alone; We give you thanks, O Lord.

- Be present at our table, Lord! Be here and everywhere adored. Your mercies bless, and grant that we may feast in Paradise with Thee. (Or: May strengthened for thy service be.)

In the meantime, the prayer for food by children include the following:

- For food and health and happy days receive our gratitude and praise. In serving others Lord may we repay our depth of love to thee.

- Thank you for the food we eat, Thank you for the world so sweet, Thank you for the birds that sing, Thank you God for everything.

- God is great, God is good. Let us thank him for our food. By his hands, we are fed. Let us thank him for our bread.

- Bless, O Lord, this food we are about to eat; and we pray You, O God, that it may be good for our body and soul; and if there be any poor creature hungry or thirsty walking along the road, send them into us that we can share the food with them, just as You share your gifts with all of us. ${ }^{1}$

These prayers receive different names or titles such as blessings for food, sanctification of food, grace over food and thanksgiving for food. Appreciation is so much on the God who provides this 
food and sometimes they are uttered with scanty mention of the poor, the hungry and the underprivileged.

Scanning through these prayers, one picks up one common thread. They mostly, if not all, acknowledge the provider (God) and the hands that prepare (cook) this food. There is a missing link, that is, the producer (farmer). The farmer is unmentioned in appreciation of food. As a producer, the farmer has become insignificant or invisible in human livelihood. This producer has become a middle mediator who is not recognised in prayers of thankfulness. The farmer is the shepherd of the nation who ensures food security and textile adornment for humanity. We all know that creatures eat in order to live, but what is the rationale behind acknowledging the sovereign provider, but ignoring the laborious producer? I concur with Conradie (2016), but does this mean that we marginalise the farmer? As stated by Conradie (2016):

All that is alive lives by eating. To eat is to participate in God's gift of life, even to participate in God's 'eternal' (perhaps ongoing?) life. The blessings from God imply that the materiality of the world is a doxological expression of God's gift; creation is a Eucharistic sign of thanksgiving. (p. 4)

\section{God is the agriculturist}

Opening the pages of the Bible, a reader is confronted with God as the Creator exercising his activities in the garden - the farm. The creation narrative revolves around the garden wherein a human being interfaces and interacts with the Creator. It was in the garden where humanity exercised humanness in fullness. Out of the garden, God gave the human being a liberty to exercise all peculiarities of wisdom. These included abilities to name creatures by their kinds and species, to make choices of obeying or disobeying God, to exercise mutual love after the institution of marriage and to enjoy the essence and the depth of fellowship with God, helpmate and other creatures. Human's first sexual experience was in the garden. God is the God of farms.

Throughout the canonical narratives, wealth and social status were derived from farming. People's wealth had always been as a result of farming. The patriarchs were nomadic, not because of peasantry, but because of seeking a better welfare for their livestock. The famine in Egypt dreamed by Pharaoh and interpreted and predicted by Joseph all centred on farming. God's people expressed their devotions to God through sacrificial items (livestock and grain) of farming activities. Job, the wealthiest man in the east, was a livestock keeper and the cultivator of the land. Boaz, the kinsman redeemer, was the tiller of the land.

The climax of the dynastic tensions in both Judah and Israel in seventh and eighth centuries was always around the farmlands. A good example here is the famous Naboth's vineyard (1 Ki 21), who 'viewed the sale of his ancestral land as the transgression of God's law' (Resane 2015a:181). He esteemed his land as more important for farming than for urban extension and occupation. Although Ahab needed a land for vegetable production, there was no guarantee of the continuing crop production as this land was adjacent to the king's palace. 'Expansion in Jezreel positioned King Ahab's palace closer to the traditional farming land' (Resane 2015a:180).

The New Testament is full of farming references. Christ used parables, and many of them are related to farming activities. These were used to uncover the truth and to drive points home. Jesus knew that his audience was familiar with these agricultural references. It is for this reason that the interpreter of the parables 'must become thoroughly conversant with the history, geography, culture, and customs of biblical times' (Pentecost 1982:16). Without the farming knowledge, interpreting parables and similes in the Bible would be impossible.

\section{Historical survey of farming in South Africa}

The history of farming dates back thousands of years and its development has been determined by climatic, cultural and technological dynamisms. As stated by Sharma (2014):

The history of agriculture has played a major role in human history, as agricultural progress has been a crucial factor in worldwide socio-economic change. (p. 1)

Back to our South African context, farming has always been the socio-economic vocation for survival and livelihood in general. The southern African subcontinent is historically a farming region of the continent. From the hunter-gatherer evolution of economic survival to the modern commercial farming, this subcontinent has always built its life around food production in a form of cultivation and livestock farming. The hunter-gatherer way of life was the economy (Du Bruyn 1992):

based on the extraction from the environment of naturally occurring food resources. In collecting edible plants, in hunting, and in preparing food for consumption they needed no more than a few simple implements made of raw materials readily at hand. (p. 20)

This is the evidence that access to food in a less technologically sophisticated environment called for some efforts to economy. The economic vocation was accessing food either for an individual, the family or the clan in order to reach the immediate needs for living.

Apart from the hunter-gatherers' indigeneity to the subcontinent, the Khoi pastoralists are known for their foodproducing revolution. The Khoi herders were and are known for their stock-keeping way of life. Their techniques of animal husbandry in southern Africa is well documented by historical anthropologists such as Sealy and Pfeiffer (2000), Voigt (1986) and Barnard (1992).

Among the Bushmen, human relationships were centred round the need for all individuals to have year-round access to widely scattered natural food resources. Among the Khoi pastoralists, whose staple foods were derived from the milk of their cows, relationships were centred round the need to 
maintain milk production at a level which could provide all members of the society with at least a minimum share (Du Bruyn 1992:25).

The livestock played some paramount role in socio-economic and socio-political life of the Khoi. Their farming practices were the means of sustenance and survival in their egalitarian society. This society 'was characterised by dependence on a pastoral economy' (Du Bruyn 1992:25). This is also confirmed by Voigt (1986):

Pastoralism is a way of life that is totally in tune with the seasonal cycle and the environmental setting of a group. The only true pastoralists in southern Africa were probably the Khoikhoi whose elusive physical remains appear to escape definition. (p. 20)

The subcontinent was later acquainted with the so-called Bantu-speaking farmers. These are the majority of the people in southern Africa, whose life vocation was and still is cultivating the land and herding the livestock. Their encounter with the European settlers is estimated to be around the second half of the 16th century, when they met the Portuguese survivors of the time. They were marked for being their own food producers rather than foragers or gatherers.

Traditionally, all the African peoples were subsistence farmers. Every family had to produce enough for its own needs by its own labour. Although there were local variations, the people were basically herders of cattle, sheep and goats, as well as cultivators of the soil (Morris \& West 1982:8). This subsistence farming clashed with the Western idea of socioeconomic competition based on performance and enrichment. Changuion and Steenkamp (2012) point out this fact:

Land was communal and not individual property and the produce of their agricultural activities was mainly for own consumption and to a lesser extent for 'selling' or barter. (p. 22)

The farming activities that included tilling the land and livestock-keeping were the centrifugal force that cemented the community or tribe. The tribal livelihood and survival depended on farming. Cattle breeding and rearing was the pride of the family. Men tilled the land and looked after the livestock's welfare, while women weeded and harvested the crops. Both men and women were economically involved.

The encounter of the Europeans and the indigenous people enhanced farming to a certain degree (Elphick \& Giliomee 1987):

A development of major significance during the first twentyseven years of European colonisation was the adoption of extensive agriculture-a reversal of the agricultural intensification process of Western Europe. (p. 48)

As Europeans moved into the hinterland from the Cape, and encountered inhabitants of the frontiers, farming became the main economic activity that demanded intensive labour. Towards the last decades of the 19th century, 'there was a gradual transition from an extensive to an intensive but commercialised agricultural industry' (Muller 1993:249). This inevitably necessitated labourers in the farming industry. The black population became the source of this labour reservoir. The interexchange of skills was subliminally transferred, and both black people and white people became farmers. This was interrupted by the discovery of diamonds and gold towards the end of the 19th century. The most affected areas were the Orange Free State and the British Cape Colony, although the impact affected and infected the Transvaal Republic, and slowly the rest of southern Africa.

The nagging labour problem, with which the farmers were increasingly faced in the nineties because they were engaged in mixed farming, is closely linked with the question of relations between white people and black people in the Free State (Muller 1993:249).

One can realise that farming has always been politicised. The politics of the land in South Africa are so intertwined with farming or agriculture. However, a special note should be heeded that farming, especially food production, is a bulwark of economic development in South Africa. Regardless of the semi-arid and arid condition of the soil, the erratic seasonal rains still usher in a chance for productive agricultural output. Most of southern Africa is arid, and hence covered with some desert soils. These soils 'are shallow, have poorly developed profiles, and lack organic matter' (Grove 1994:47).

Until recently, agriculture was the chief means of subsistence for most of the inhabitants of Africa (Ferreira 1993:55). It is still a chief source of employment for many black South Africans. Farming is potentially the major generator of economic growth.

\section{The current status of farming in South Africa}

South Africa is one of the developing nations that is extensively engaged with commercial farming. It is still riddled with the racial imbalances of the past. Through the Bantustan system of the British and apartheid laws, the minority white people ended up owning $87 \%$ of the fertile land, while the majority black people ended up owning the unproductive $13 \%$ of the land. Or as Hodson (1996:12) puts it: 'The results of this long period of discrimination resulted in $20 \%$ of the population holding $87 \%$ of the land'. This confirms Mogashoa's (2005:277) argument 'that natives were relocated to and "given" unsuitable and unliveable, poor land'. Malan (2015:410) describes these homelands or Bantustans as 'ecological Hiroshima'. This is the historical fact that has led to the plight of farming and the current disrespect of farmers in South Africa (Resane 2015a):

In South Africa, the dispossession process by European settlers started in the 17th century. The indigenous societies lost their land, as the dispossession process played a key role in creating a racially polarised and unequal society. The Glen Grey Act (1894), The Native Land Acts (1913 and 1936), dispossessed and disempowered the indigenous Africans of the land ownership. The situation was exacerbated between 1948 and 1990 when the 
apartheid government relocated millions of Black people to some Bantustans known as homelands, or newly created townships. The so-called Black spots were removed and resettled in these racial zones. This was known by the then media of South Africa as 'forced removals'. (p. 176)

The Balkanisation of South Africa into the Bantustan conglomerates plunged the majority black citizens into abject poverty. This notorious Land Act was one of the enhancements of the arcana of apartheid (Hall 2014):

The Act's provisions were fairly straightforward: 'scheduled areas' were created to serve as native reserves on about 7 percent of the country's land. (p. 1)

These reserves (homelands) disempowered the majority citizens and empowered the minority who currently possess the monopoly of farming. From the middle of the 20th century, the then South African government embarked on empowering the white farmers, as pointed out by Davenport (1991):

The tendency to over-promote white economic interests extended to white agriculture, in particular to maize industry which was 'spoonfed to high production levels', especially after the Marketing Act of 1937... Over the years this meant the budgetary starvation of black farming. (p. 487)

This legacy was passed on to the current generation. Farming is a white business, and although the black people are still struggling to regain the land, commercial farming is still a white monopoly. Many black people have not acquired skills for farming. The return of the arable land to their hands is questionably reserved for productive output. This is a sad picture as painted by Mogashoa (2005):

With natives generally dispossessed of their land and the Europeans in possession of it, a new relation to the land had evolved. With ownership of the land in their hands, the Europeans enjoyed better livelihoods. Sadly for the natives, as they were landless, they had to trade their labour to generate income. In other words, the land, for the natives, was no longer a source of economic wealth. This kind of scenario also played itself out within the church. (pp. 280)

The sadness of the situation is exacerbated by the ignorance of farming. For some professional black people, farming is never a full-time job, but a pastime activity. In some cases, it is regarded as a hobby - something like a picnic spot for a weekend chill-out. Many black people are still attached to their traditional notions where 'cattle, is the preserve of the men, had great importance in tribal society and this is reflected in the interest taken in them' (Morris \& West 1982:8).

\section{The South African farm attacks}

The term 'farm murders' has become fundamentally politicised, associated with false right-wing claims about 'white genocide'. Farmers say that they are under siege, that farm attacks are on the rise and that both the media and the government prefer to turn a blind eye to their plight rather than taking them seriously. A recent report about farm attacks reaching record levels over January and February failed to make it much beyond the Afrikaans press (Davis 2017).

The majority of commercial farmers in South Africa are white people, with a small number of black entrants into the farming industry since the 1990s. Historically, the white farmers were noted for brutality and enslavement of the black labourers on the farms. This is one of the contributing factors towards farm murders. The recent debate in parliament between the Economic Freedom Fighters (EFF) and Freedom Front Plus (FF+) shows that some farm attacks are motivated by hatred and anger. This is politically sensitive, but cannot be dismissed.

There has been an ongoing trend of violent attacks on farmers since 1994. Some statistics show that between January 1990 and March 2012, there had been 1544 murders on South African farms of which 208 of the victims were black people.

The reasons why farms are targeted for robberies include their geographical isolation, the patchy police services, the loneliness of farm house elderly individuals and farm households perceived as sites where weapons are stacked and can be stolen (Davis 2017).

Some political figures see farm attacks as a form of retribution for the injustices and dispossession of the past. The murders of black people on farms are not counted. Occasionally people react when white farmers are slain. If you look at the gruesome manner in which farmers are attacked, it is more like a response or revenge. Even the farmers that are not involved in brutality end up becoming victims because of the culture of violence. The death of these farmers is minuscule compared to the horrors that black people face (Mngxitama).

White farmers' rights activists maintain the opposite: that both the mainstream media and the government prefer to turn a blind eye to the issue. Many white farmers perceive the attacks to be racially motivated, while many black farmers perceive murders as labour related. Attacks on farms and smallholdings refer to acts aimed at residents, workers and visitors to farms and smallholdings. The motive might be intentionally to murder, rape, rob or inflict bodily harm. In addition, actions might be aimed at disrupting farming activities as a commercial concern, whether for motives related to ideology, labour disputes, land issues, revenge, grievances or intimidation.

\section{Addressing the problem Political initiatives revisited}

The government's initiatives regarding land restitution have some shortcomings. One of the aims of land restitution was human relations in the spirit of reconciliation. This is expressed by Hall (2014) that: 
One of the goals of restitution was to create 'reconciled' communities, yet the process itself involves little evidence of attempts to reconcile. (p. 10)

This is the unfortunate situation as the objective was somehow either diluted or ignored during the process. Hall (2014) continues that:

the restitution process focused only on the material question of restoring land or granting compensation in the form of cash. Restitution was separated from human relations. (p. 10)

The government has been accused of either putting in too much effort (Manby 2001) or not enough effort (The Times, 7 April, 2011) to tackle the problem of farm attacks as opposed to other forms of violent crime. A Committee of Inquiry into Farm Attacks was appointed in 2001 by the National Commissioner of Police. The purpose of the committee was to (Du Plessis et al. 2003):

inquire into the ongoing spate of attacks on farms, which include violent criminal acts such as murder, robbery and rape to determine the motives and factors behind these attacks and to make recommendations on their findings. (p. 18)

Some of the findings of the committee included issues such as the following:

- Monetary theft occurred in 31.2\% of the farm attacks.

- Stolen firearms were in $23.0 \%$ of the farm attacks.

- Vehicular thefts occurred in $16.0 \%$ of the farm attacks.

The committee's findings were rejected by some farming community formations and politicians. For instance, Gideon Meiring, the chairperson of the Transvaal Agricultural Union (TAU), criticised the South African Police Services (SAPS) for failing to prevent the farm attacks (Ntsaluba 2008). Kallie Kriel of AfriForum levelled attacks against the Agriculture Minister, Lulu Xingwana, and her deputy, Dirk du Toit, of inciting hatred against farmers. The two ministers claimed that 'those who inflame hate and aggression towards farmers have to be regarded as accomplices to the murder of farmers' (Azad 2013).

The issue of farm attacks still surfaces in parliament for robust debate. This is in itself a demonstration that the government or lawmakers take the matter seriously, although the issue had been politically sectionalised.

\section{Land restitution}

The black communities are cashing on their once whiteowned farmland by selling it back to its original owners. They opt to be compensated financially rather than returning and settling into the land to become partakers in commercial farming. This is because of the principle of 'willing seller, willing buyer' which had become a political hot potato in the recent past. The South African government has spent a fortune trying to redistribute the country's land wealth from the white minority to the black majority. It has bought thousands of hectares of white-owned farmland and either given it or sold it on to poor black people (Newling 2011).
This is confirmed by Minister Gugile Nkwinti as per Newling's report that black farmers have resold nearly $30 \%$ of the white farmland bought for them by the government. The minister is quoted as saying that (MailOnline, 1 September, 2011):

'The government bought land and handed it over to aspirant farmers who then sold it again, in many instances back to the original owner.'

It is clear then that land restitution is not going towards the direction of black people re-possessing the land as intended. Farming still reverts into the hands of the white commercial farmers. The state needs to invest significantly into research into how to instil the passion for farming into black citizens, so that land restitution could be beneficial for the historically marginalised poor. Bennie van Zyl, general manager of TAU, told the Daily Maverick (01 March, 2017) that:

\begin{abstract}
'The biggest asset any government can have is a productive commercial farmer. You cannot spread politics over bread and feed the nation.'
\end{abstract}

Recent research and studies have shown that as many as $90 \%$ of the new black-run farms fail because the new owners do not have the experience of running a large enterprise. The emerging farmers should bear in mind that sustainable agriculture is a journey rather than a destination. Within the properly regulated confides, God's gifts must be shared, which is the ethical principle in a concrete and suitable way (Vorster 2016:7). My argument is that land restitution needs some level of cooperation between the possessor and the dispossessed. The two must work symbiotically for the sake of the food security in the land. Reconciliation, respect, sacrifice and mutual trust should remain supreme. This is further explained by Conradie (2016):

To establish and sustain relationships requires giving and receiving. This may be interpreted in terms of the Christological category of kenosis, i.e. self-emptying for the sake of the other, or (more appropriately) for the sake of loving relationships, based on mutual respect, mutual care and mutual trust. Whenever such relationships are distorted, this requires a spirit of forgiveness but also a willingness to make oneself vulnerable by waiting upon a reciprocal response from the other. Such selfemptying is not necessarily for the sake of the other (although that is sometimes required) but at best for the sake of a flourishing relationship - of which the one making the sacrifice forms part. Food is thus God's gift of love for the sake of love. (p. 6)

\section{Agricultural sciences decolonised}

The public universities and colleges that offer agricultural sciences should re-look at the contents of their curriculum. The type of agricultural skills taught must aim to produce farmers rather than administrators. The curriculum content should aim at 'African solutions, using African methods and African technologies' (Malan 2015:444). It should offer an approach which is profitable, environmentally sound and beneficial to family and community interaction, of course with a goal in mind of exportation. Students of agriculture 
should acquire learning that 'involves both the reproduction of cultural traditions and the creation of new knowledge through innovation and discovery' (Simpson 1999:99). Services for advancement of commercial farming should be made available and accessible to all those engaged in farming. Kirsten and Van Rooyen's (2011:269) research on NoordwesKöoperasie (NWK) found out that it 'presents a comprehensive network of support services and systems to farmers in North West Province'. The services include support regarding agricultural management such as soil and economic analyses, irrigation scheduling, fertilisation and spraying programmes. The farmers affiliated to NWK are from all races and include blackfarmers from theerstwhilehomeland of Bophuthatswana. It assists its affiliates, emerging farmers and non-affiliates at differing prices. This is an attempt at decolonised farming in a racially biased industry.

\section{The church's role}

The role of the church in restoring the dignity of humanity in the midst of farm murders is inevitable and non-negotiable. The socio-political involvement of the church is almost sacrosanct. It is the divine calling transcendent to political boundaries. The solidarity with the victims of justice is what the church is all about. This calls for questioning the foundational dictum (Thesnaar 2014):

On a political and economic level, (functional) solidarity with those who suffer means a radical questioning of the structures of socio-political power that are usually taken for granted. (p. 5)

The Kairos Document (1985) refers to Church Theology. This theology was embraced in apartheid South Africa by many churches. It drew dichotomy between church and politics. Felipe Gustavo Koch Buttelli (2014) refers to it as a theology that:

Fosters a non-political spirituality, conceiving that religion and politics are separated things. This theological approach is more concerned with internal routines of the churches. (p. 90)

The danger faced by the church embracing this theology is neutrality or lukewarmness that was seen as the Church of Laodicea of Revelation 3:14-22. This theology fails the victims because of (Resane 2016):

its emphasis on incarnation within the unjust social systems, without making an analysis of these systems. In so doing, it empowers those in power to continue their evil systems such as corruption, without any fear of being a prophetic voice calling to the contrary. (p. 57)

Landlessness goes together with poverty. The landless are also the poorest of the poor. Land that should be offering food and spatial freedom has become sacrosanct and does not belong to the poor but to the rich. It is for this reason that the church should take the side of the poor to work towards equality. Preference for the poor had been misinterpreted to mean robbing Peter to pay Paul. Nothing is far from the truth (Bedford-Strohm 2012):
Preference for the poor does not aim at excluding the rich but it intends to include those who are now excluded from the benefits of society. This preference is a necessary step on the way to the inclusion of everyone in the benefits of mutual cooperation. (p. 2)

The church must become contextual in endeavouring to find solutions to farm murders. It must continue its educational task of revealing the dignity of humanity. This education should include the role and the dignity of the farmer in general (Resane 2015b):

The role of ekklesia is therefore to proclaim the gospel of the kingdom. The ekklesia belongs to the present aeon and therefore has to challenge social injustices prevalent in the cosmos. Its presence in this age necessitates the proclamation of the truth; hence ekklesia will always be in conflict with everything opposed to the truth, because the truth is existentially in combat with evil. (pp. 4-5)

The church must be unapologetically involved by providing any or all pastoral care needed by both the farm attackers and the victims. As mentioned, awareness must be raised and intervention enacted. Earl (1999) provides some wisdom here:

The Church must realize the need to respond through raising awareness of crime's impact, channelling that awareness, and incorporating that awareness into missions. (p. 240)

\section{Conclusion}

\section{Farmers are also human beings}

Africans have an emotional attachment to the land. Land is their treasured possession. The fact remains that land ownership empowers owners for socio-economic survival (Hewitt 2016):

Land constitutes the fundamental resource that forms the identity of a people. People without a strong connection to land become easy victims of political and economic exploitation. (p. 1)

This aligns with the Old Testament teaching regarding the land. Fischer (2016) correctly asserts:

God is seen as the creator of all land (Psalm 24); all things belong in an ultimate sense to him, so the position of humanity is that of stewards. Land was seen as a gift to be passed on, not only from one generation to the next, but passed on within families. The approach to land was designed to prevent the growth of individualistic accumulation of land as well as the centralizing of power in the state. Ideally, in the Old Testament, land was to be owned in perpetuity within families. This is the explicit meaning of the Jubilee. (Lv 25:8-11). (p. 6)

This Levitical notion is furthered by De Vries (1998:174) that 'No land shall be sold outright, because the land is mine, and you are coming to it as aliens' (Lev 25:23). Farming is an honourable career that provides nations with food and body adornment necessities. As farming is on the land, there is a call of some form of stewardship in caring for the land. Christians 'are partners with God for caring, sustaining, and protecting creation as opposed to lording over it'. (Resane 2015a:2). The inhabitants of the land, who might be the 
farmers need to be given respect as they are also humans carrying the image of God. Farmers are not to be murdered, but be engaged in conversation regarding land restitution. Murder, robbery and theft are not crimes to be justified under any circumstances. These crimes undermine human life and dignity. All humans possess the right to life, and only Creator should terminate that life.

A farmer is the feeder of the nation. Without the farmer, humans will starve to death. Referring to Psalm 23, Resane (2014:1) alludes to the synergy between the farmer and the shepherd:

In a general sense a shepherd refers to a keeper of sheep. This is the person who tends, feeds, or guards the flocks. The Hebrew word for shepherding is often translated as 'feeding' as it is impressed by the next statement, 'I shall not want' or 'I shall lack nothing' - alluding to the fact that the Psalmist means he will lack neither in this life nor in the next. (p. 1)

The farmers are the hands that feed us, therefore are not to be bitten. Farmers, regardless of their colour, race or creed, are also human beings carrying the image of God. They are in synergy with God's plan and purpose of tilling the land. Murdering or stealing from them because of the sociohistorical factors cannot be justified (De Vries 1998):

When man turns his back on the Creator's plan, he provokes a disorder which has inevitable repercussions on the rest of the created order. If men and women are not at peace with God, the earth itself cannot be at peace. (p. 117)

The commandment, 'You shall not murder', is specifically directed to the respect and preservation of human life. Human life is precious in the eyes of the Lord. No other human is allowed under any circumstances to take another's life (Pope John Paul II cited by De Vries 1998):

Respect for life, and above all the dignity of the human person, is the ultimate guiding norm for any sound economic, industrial or scientific progress. (p. 117)

The bottom line of the matter is mutual respect, mutual trust, reconciliation and preserving the dignity of farmers as people created in God's image. They are to be appreciated, prayed for and acknowledged as the main role players in food production and security.

\section{Acknowledgements Competing interests}

The author declares that he has no financial or personal relationships that may have inappropriately influenced him in writing this article.

\section{References}

Azad, E., 2013, 'South Africa's 'miracle transition' has not put an end to white privilege', The Guardian, archived from the original on 26 September 2014 viewed01March 2017, from https://www.theguardian.com/commentisfree/2013/ oct/21/south-africa-white-privilege-afrikaner

Barnard, A., 1992, Hunters and herders of southern Africa: A comparative ethnography of the Khoisan peoples, Cambridge University Press, Cambridge.

Bedford-Strohm, H., 2012, 'Food justice and Christian ethics', Verbum et Ecclesia 33(2), Art. \#768, 6 pages. https://doi.org/10.4102/ve.v33i2.768
Buttelli, F.G.K., 2014, “'Liberative Justice - A Brazilian Response to Kairos Palestine" A moment of truth struggles of the occupied people for the right to life', Theologies and Cultures XI(1), 84-96.

Changuion, L. \& Steenkamp, B., 2012, Disputed land: The historical development of the South African Land Issue, 1652-2011, Protea Book House, Pretoria.

Conradie, E., 2016, 'What do we do when we eat? Part II. A theological inquiry', Scriptura 115(1), 1-21, viewed 11 April 2017, from http://scriptura.journals.ac.za Davenport, T.R.H., 1991, South Africa: A modern history, Macmillan Press LTD, London.

Davis, R., 2017, “Rural safety: Are farm murders being underplayed for politics?', Daily Maverick, viewed 01 March 2017, from https://www.dailymaverick.co.za/
article/2017-03-01-rural-safety-are-farm-murders-being-underplayed-forpolitics/\#.WxFA_OhuZPY

De Vries, B.A., 1998, Champions of the poor: The economic consequences of JudeoChristian Values, Georgetown University Press, Washington, DC.

Du Bruyn, J.T., 1992, Themes in the Early History of Southern Africa, Reader for HST100-M, University of South Africa, Pretoria.

Du Plessis, C.F, De Haas, M.E.A, Dhlamini, J., Mistry, D., Moolman, C.J., Rasegatla, M., et al. 'Report of the Committee of Inquiry into Farm Attacks - 31 July 2003', viewed 07 March 2017, from https://africacheck.org/wp-content/uploads/2013/11/FinalReport-Committee-of-Inquiry-Farm-Attacks-July-2003.pdf

Earl, L.A., 1999, 'The spiritual problem of crime: A pastor's call', in L.B. Lampman \& M.D. Shattuck (eds.), God and the victim: Theological reflections on evil, victimization, justice, and forgiveness, pp. 235-249, Wm B Eerdmans \& Neighbours Who Care (NWC), Grand Rapids, MI.

Elphick, R. \& Giliomee, H., 1987, The shaping of South African Society 1652-1820, Maskew Miller Longman, Cape Town.

'Farms of Fear', The Times, UK, 07 November 2009, viewed 30 March 2017, from http://censorbugbear-reports.blogspot.co.za/2009/11/farms-of-fear-sundaytimes-london.html

Ferreira, S.L.A., 1993, 'Agricultural Development in Africa', in Geography (BA) Only study guide for GGE203-H (Unbalanced Politicospatial Organisation), pp. 55-64, UNISA, Pretoria.

Fischer, J., 2016, 'A biblical/cultural perspective on land in Southern Africa', paper presented at the annual conference of the Theological Society of South Africa, Pretoria, on 13 July 2016, pp. 1-16.

Grove, A.T., 1994, The changing geography of Africa, 2nd edn., Oxford University Press, Oxford.

Hall, R., 2014, 'The Legacies of the Natives Land Act of 1913', Scriptura 113(1), 1-13, viewed 01 March 2017, from http://scriptura.journals.ac.za

Hewitt, R., 2016, 'Stealing land in the name of religion: A Rastafari religio-political critique of land theft by global imperial forces', HTS Teologiese Studies/Theological Studies 72(1), a3347. https://doi.org/10.4102/hts.v72i1.3347
Stiti

Hodson, T.A., 1996, South African land tenure, past and present: A country report, Department of Spatial Information, Science and Engineering, University of Maine, Orono, ME.

Kairos Theologians, 1985, The Kairos Document: Challenge to the Church, Theological Comment on the Political Crisis in South Africa, Wm. B Eerdmans Publishing, Grand Rapids, MI.

Kirsten, J. \& Van Rooyen, J., 2011, 'NWK Limited: Introduction and company overview', in E. Mabaya, K. Tihanyi, M. Karaan \& R. Van Rooyen (eds.), Case studies of emerging farmers and agribusiness in South Africa, pp. 268-275, Sun Press, Stellenbosch.

Malan, R., 2015, My Traitor's Heart: Blood and bad dreams: A South African explores the madness in his country, his tribe and himself, Vintage Books, London.

Manby, B., 2001, 'Unequal protection - The State response to violent crime on South African Farms', Human Rights Watch, viewed 17 April 2017, from https://www. hrw.org/reports/2001/safrica2/Safarms8.htm

Mogashoa, M.H., 2005, 'South African Baptists and the Land Discourse (1806-1913)', Studia Historiae Ecclesiasticae XXXI(2), 269-285.

Morris, J. \& West, M., 1982, Abantu: An introduction to the Black People of South Africa, C. Struik Publishers, Cape Town.

Muller, C.J.F., 1993, Five hundred years: A history of South Africa, Academica, Pretoria.

Newling, D., 2011, 'Black farmers in South Africa cash in by selling land given to them by the government... back to whites who originally owned the farms', MailOnline 01 September, 2011, viewed 19 March 2017, from http://www.dailymail.co.uk/ news/article-2032588/Black-farmers-South-Africa-cash-selling-land-givengovernment--whites-originally-owned-farms.html

Ntsaluba, G., 2008, 'Anti-Farmer hate speech slated', News24.com, viewed 24 March 2017, from https://wikivividly.com/wiki/South_African_farm_attacks

Pentecost, J.D., 1982, The Parables of Jesus, Kregel Publications, Grand Rapids, MI.

Resane, K.T., 2014, 'Leadership for the church: The shepherd model', HTS Teologiese Studies/ Theological Studies 70(1), Art. \#2045, 6 pages. https://doi.org/10.4102/ hts.v70i1.2045

Resane, K.T., 2015a, 'Naboth's Vineyard: Theological lessons for the South African Land Issue', Acta Theologica 35(1), 174-188, viewed 17 March 2017, from http:// www.ufs.ac.za/ActaTheologica.

Resane, K.T., 2015b, 'The mining-induced displacement and resettlement: The church as a leaven and ecclesiology in context's response', HTS Teologiese Studies/Theological Studies 71(3), Art. \#2967, 8 pages. https://doi.org/10.4102/hts.v71i3.2967

Resane, K.T., 2016, 'Africanising a theological discipline: Paradigm shifts for the new trends', in R. Venter (ed.), Theology and the (Post) Apartheid Condition: Genealogies and future directions, pp. 50-72, Sun Media, Bloemfontein. 
Sealy, J. \& Pfeiffer, S., 2000, 'Diet, body size, and landscape use among Holocene People in the Southern Cape, South Africa', Current Anthropology 41(4), 642-655. The University of Chicago Press on behalf of Wenner-Gren Foundation for Anthropological Research Stable, viewed 21 April 2017, from http://www.jstor.org/stable/10.1086/317392

Sharma, S., 2014, Agriculture, poverty, unemployment and sustainability, Global Publications, New Delhi.

Simpson, B.M., 1999, The roots of change: Human behaviour and agricultural evolution in Mali, Intermediate Technology Publications, London.

The Citizen, 2017, 'Mngxitama tells Anneline Kriel farm murders are black revenge' viewed 16 April 2017, from https://citizen.co.za/news/south-africa/1439031/ mngxitama-tells-anneline-kriel-farm-murders-black-revenge/
Thesnaar, C., 2014, 'Rural education: Reimagining the role of the church in transforming poverty-stricken South Africa', HTS Teologiese Studies/ Theological Studies 70(1), Art. \#2629, 7 pages. https://doi.org/10.4102/

Voigt, E.A., 1986, 'Iron age herding: Archaeological and ethnoarchaeological approaches to pastoral problems', Goodwin Series, Vol. 5, in Prehistoric Pastoralism in Southern Africa, pp. 13-21, South African Archaeological Society Stable, viewed 21 April 2017, from http://www.jstor.org/stable/3858141

Vorster, J.M., 2016, "'Get out and gather each day..." The implications of the ethics of Exodus 16 for modern consumerism', paper presented at the Annual Conference of Theological Society of South Africa, University of Pretoria, Faculty of Theology, North-West University (Potchefstroom Campus), 14th July 2016. 